\title{
CRITICAL ANALYSIS OF THE ALLOCATION POLICY FOR LIVER TRANSPLANTATION IN BRAZIL
}

\author{
Hoel Sette Jr., Telesforo Bacchella and Marcel Cerqueira César Machado
}

SETTE Jr. H et al. - Critical analysis of the allocation policy for liver transplantation in Brazil. Rev. Hosp. Clín. Fac. Med. S. Paulo 58(3):179-184, 2003.

Liver transplantation is now the standard treatment for end-stage liver disease. Given the shortage of liver donors and the progressively higher number of patients waiting for transplantation, improvements in patient selection and optimization of timing for transplantation are needed. Several solutions have been suggested, including increasing the donor pool; a fair policy for allocation, not permitting variables such as age, gender, and race, or third-party payer status to play any role; and knowledge of the natural history of each liver disease for which transplantation is offered. To observe ethical rules and distributive justice (guarantee to every citizen the same opportunity to get an organ), the "sickest first" policy must be used. Studies have demonstrated that death has no relationship with waiting time, but rather with the severity of liver disease at the time of inclusion. Thus, waiting time is no longer part of the United Network for Organ Sharing distribution criteria. Waiting time only differentiates between equally severely diseased patients. The authors have analyzed the waiting list mortality and 1-year survival for patients of the State of São Paulo, from July 1997 through January 2001. Only the chronological criterion was used. According to "Secretaria de Estado da Saúde de São Paulo" data, among all waiting list deaths, $82.2 \%$ occurred within the first year, and $37.6 \%$ within the first 3 months following inclusion. The allocation of livers based on waiting time is neither fair nor ethical, impairs distributive justice and human rights, and does not occur in any other part of the world.

DESCRIPTORS: Liver transplant. Allocation criteria. Survival prognostic models.

Liver transplantation is now the standard treatment for end-stage liver disease. However, given the shortage of liver donors and the progressively higher number of patients on the waiting list for liver transplantation, improvements in patient selection and optimization of timing for transplantation are needed ${ }^{1,2}$.

The first step towards improving the selection process is to introduce greater uniformity of the patient selection process between different transplant programs. The earlier the transplant is done in the course of progressive liver disease, the better are the operative and immediate postoperative outcomes. On the other hand, organs have become scarce relative to the number of potential recipients as the number of transplant programs has grown. Because of the uncertainty of organ availability, patients are placed on waiting lists earlier to ensure receiving an organ before serious deterioration has occurred. As of 1998, the Child-Turcotte-Pugh (CTP) classification has been used when minimal listing criteria were defined ${ }^{3}$. Even so, patients may wait for months or even years for an organ, during which time their health and candidacy may deteriorate. To solve this problem, several improvements are needed. First, effective steps must be taken to improve the

From the Department of Surgery, Faculty of Medicine, University of São Paulo - São Paulo/SP, Brazil.

Received for publication on Sepetember 28, 2001. size of donor pool ${ }^{4,5}$. Second, a fair ${ }^{6}$ policy of organ allocation that maximizes the utilization of available organs must be agreed to by all, not permitting a number of models that use politically charged variables such as age, gender, and race, or third-party payer status, which would discriminate against some groups of patients and therefore could not be incorporated in a model to be used nationally to select patients for organ allocation ${ }^{7-9}$. Third, the natural history of each liver disease must be defined for the different diagnoses for which transplantation is offered. And finally, to observe ethical rules and distributive justice (guarantee to every citizen the same opportunity to get an organ) the "sickest first" policy ${ }^{10}$ should be used. 
However, liver transplantation is still a risky process. Thus, one should consider the morbidity and mortality (rejection, infections, biliary problems, primary nonfunction, etc.) when indicating a liver transplantation. Some patients may remain alive and stable on conservative medical or surgical therapy ${ }^{1}$.

At the same time, since long-term survival improves after liver transplantation, cardiovascular complications, among others, are emerging as a major cause of morbidity and mortality ${ }^{11}$. Additionally, recurrence of the liver disease (hepatitis B and C, primary biliary cirrhosis, primary sclerosing cholangitis, autoimmune hepatitis, or alcoholic cirrhosis), de novo malignancies, and bone disease should be taken into account when determining suitability for liver transplantation ${ }^{12-18}$.

Liver transplantation has evolved over the past 30 years from a rather dramatic and desperate surgical rescue of patients with end-stage liver disease to a commonplace treatment modality, with nearly 5,000 liver transplants being performed yearly in the United States $^{19}$. Indeed, some 40,000 patients in the United States have undergone liver transplantation in the past decade. Today in the USA, survival after liver transplantation is $90 \%$ within 1 year and approximately $75 \%$ at 5 years $^{12}$. Over the past few years, donor organ allocation policy and liver allocation in particular have been intensely scrutinized and criticized by the press and by the federal government ${ }^{20}$. Much of the criticism has focused on the wide variations in the time that candidates for liver transplantation must wait for an organ and on the geographic correlation of these differences ${ }^{21}$. However, many liver specialists have argued that waiting time for liver transplantation is not a good measure of a program's performance ${ }^{22-24}$.

In April 1998, the US Department of Health and Human Services (DHHS) issued the final ruling, in which the principles of allocation policies and procedures were defined in order to guide the Organ Procurement and Transplant Network (OPTN) ${ }^{25}$. These rules included allocation of organs among transplant candidates following a medical urgency criterion that minimized the role of waiting times and avoided futile transplantation while promoting efficient management of organ placement. A subsequent report from the Institute of Medicine, commissioned by USA Congress, concluded that the liver allocation system based in waiting times was not fair ${ }^{26}$.

More recently, Freeman et al. ${ }^{30}$ studied factors associated with the risk for mortality once an individual is placed on the liver transplant waiting list and how this risk relates to centerspecific waiting times and transplant activity. A Cox proportional hazard model was used to calculate the 2-year mortality risk for a cohort of 16,414 registrants added to the United Network for Organ Sharing liver transplant waiting list between January 1, 1997, and December 31, 1997. After controlling for confounding variables, they calculated the mortality risk for centers, organ procurement organizations (OPOs), and states. The relationship between center-specific waiting list mortality risk and median waiting time or transplant activity was determined by linear regression. In multivariate analysis, higher initial medical urgency status (relative risk $[\mathrm{RR}]=12.8 ; P<.001)$, increasing age $(\mathrm{RR}=1.2 ; P<.001)$, black ethnicity (RR $=1.29 ; P<.001)$, history of previous transplant $(\mathrm{RR}=1.2 ; P=.009)$, smaller center size $(\mathrm{RR}=1.39 ; P$ $=.008$ ), and certain liver diagnoses were associated with significantly increased waiting list mortality. There were significant variations in 2-year waiting list mortality risk among centers, OPOs, and states. However, when stratified by medical urgency status at waiting list entry, center-specific waiting time and transplantation rates accounted for almost none of the center-specific waiting list mortality. These investigators concluded that waiting time and center transplant rates should not influence liver allocation policy ${ }^{27}$.

Thus, the Freeman study results clearly indicate that the United Network for Organ Sharing (UNOS) medical urgency categories, as defined in his study, have a significant relationship to the risk for death on the list. Despite the methodologic differences, these 2 separate and independent studies confirm that status-specific (IOM analysis) and patient-specific (Freeman's study) waiting times are not related to the risk of death on the waiting list and should discredit the utility of waiting times as a criterion for liver allocation. Using medical urgency as the primary criterion for determining the selection of liver transplant recipients is sometimes referred to as the "sickest first" policy ${ }^{28}$.

A recent mandate emphasizes the use of the severity of liver disease to determine priorities in allocating organs for liver transplantation and necessitates a disease severity index based on generalizable, verifiable, and easily obtained variables ${ }^{26}$.

Before this development, on February 21, 2000, Freeman et al., implemented a variance to the UNOS liver allocation policy that redefined status $2 \mathrm{~A}$ with much more rigid, definable criteria and prioritized status $2 \mathrm{~B}$ patients by using a continuous medical urgency score based on the ChildTurcotte-Pugh score and other medical conditions. In this system, waiting time is used only to differentiate status $2 \mathrm{~B}$ candidates with equal medical urgency score. A continuous medical urgency scoreis particularly problematic for patients classified as status $2 \mathrm{~B}$, who form the largest group of patients undergoing liver transplantation 
(56\%) and who exhibit a broad range of liver disease severity ${ }^{29}$.

Comparing the 6-month period (period $1 ; \mathrm{n}=67$ ) before implementation of this system to 6-month period after implementation (period $2 ; \mathrm{n}=$ $75)$, there was a significant reduction in the number of transplants performed for patients listed as status $2 \mathrm{~A}(46.3 \%$ to $14.7 \% ; P=.002)$ and an increase in the number of patients listed as status 2B who received transplants ( $44.8 \%$ to $70.7 \% ; P=.10)$. Most dramatically, there was a $37.1 \%$ reduction in overall deaths on the waiting list, from 94 deaths in period 1 to 62 deaths in period $2(P=.005)$, with the most significant reduction for patients removed from this list at status $2 \mathrm{~B}(52 \mathrm{v} 18 \mathrm{pa}-$ tients; $P=.04$ ). There were 3 postoperative deaths in each period, with only 1 graft loss in period 2. Status 2B patients with the greatest degree of medical urgency received transplants without multiple peer reviews of requests for elevation to 2A status. In summary, the continuous medical urgency score system allocates donor livers much more fairly to those in medical need and reduces waiting list mortality without sacrificing efficacy ${ }^{30,31}$.

More recently, Kamath, et al. ${ }^{33}$ adapted a model designed to predict poor survival in patients undergoing transjugular intrahepatic portosystemic shunts (TIPS) to treat refractory ascites ${ }^{32}$. This system, called the Model for EndStage Liver Disease (MELD) utilizes serum bilirubin and creatinine levels, international normalized ratio (INR) for prothrombin time, and the etiology of the liver disease. The model's validity was tested in 4 independent data sets, including (1) patients hospitalized for hepatic decompensation (referred to as "hospitalized" patients), (2) ambulatory patients with noncholestatic cirrhosis, (3) patients with primary biliary cirrhosis (PBC), and (4) unselected patients from the 1980s with cirrhosis (referred to as "historical" patients). In these pa- tients, the model's ability to classify patients according to their risk of death was examined using the concordance (c)-statistic. The MELD scale performed well in predicting death within 3 months, with a c-statistic of 0.87 for hospitalized patients, 0.80 for noncholestatic ambulatory patients, 0.87 for PBC patients, and 0.78 for historical cirrhotic patients. Individual complications of portal hypertension had minimal impact on the model's predictive power (range of improvement in c-statistic: <.01 for spontaneous bacterial peritonitis and variceal hemorrhage to ascites: 0.0 to 0.03 ). The MELD scale proved to be a reliable measure of mortality risk in patients with end-stage liver disease and suitable for use as a disease severity index to determine organ allocation priorities.

\section{WHAT IS MELD?}

The Model for End-Stage Liver Disease (MELD) $)^{34}$ is a numerical scale, ranging from 6 (less ill) to 40 (gravely ill), that has been used as an organ allocation criterion for adult liver transplant candidates in the USA, as of February 2002. It gives each individual a 'score' (number) based on how urgently he or she needs a liver transplant within the next 3 months. The number is calculated using a formula that includes 3 routine lab test results:

- bilirubin, which measures how effectively the liver excretes bile;

- INR (prothrombin time), which measures the liver's ability to make blood clotting factors; and

- creatinine, which measures kidney function. (Impaired kidney function is often associated with severe liver disease.)

The MELD score replaced the previous Status 2A, 2B, and 3 categories. Upon initiating the use of the MELD criterion, the status 1 category (patients who had acute liver failure and a life expectancy of less than 7 days without a transplant) remained in place as the highest priority for receiving an organ, and is not affected by the use of the MELD system.

A patient's score may go up or down over time depending on the status of his or her liver disease. Many patients have their MELD score assessed a number of times while they are on the waiting list. This helps ensure that donated livers go to the patients in greatest need at that moment.

A patient who does not have a MELD score that, in the judgment of his transplant physician, appropriately reflects the patient's medical urgency may nevertheless be assigned to a higher MELD score upon application to and justification by the appropriate Regional Review Board (RRB).

Special cases are HCC (hepatocellular carcinoma), HPS (hepatopulmonary syndrome), familial amyloidosis, and some other cases not specified. Applications for MELD score exceptions require prospective RRB approval. The listing center completes a MELD Exception Application online. $\mathrm{UNet}^{\mathrm{SM}}$ shows completed applications as 'Pending'. The UNOS then blinds patient and center information, and releases the blinded application to RRB members for medical review. $\mathrm{UNet}^{\mathrm{SM}}$ indicates 'Submitted to RRB'. When the RRB has reached a majority vote, $\mathrm{UNet}^{\mathrm{SM}}$ indicates a majority decision. If the requested higher MELD score is approved, the MELD score used by the liver-matching system is immediately updated on the candidate's waiting list registration. If the requested higher MELD score is not approved, the center can choose to appeal or not appeal.

\section{HCC MEDICAL CRITERIA}

Applications involving HCC do not require prospective RRB approval: $\mathrm{UNet}^{\mathrm{SM}}$ assigns a MELD score of $15 \%$ mortality risk for $\mathrm{HCC}$ patients 
with tumor size $<2 \mathrm{~cm}$, or MELD score of $30 \%$ mortality risk for $\mathrm{HCC}$ patients with tumor size $\geq$ to $2 \mathrm{~cm}$, or multiple lesions with the largest being $<3 \mathrm{~cm}$.

\section{INITIAL REGISTRATION CRITERIA}

Patients need to undergo an evaluation of the number and size of tumors. The assessment must include ultrasound of the liver, CT or MRI of the abdomen and chest, and a bone scan AND one of the more invasive procedures listed in policy. For a tumor $>1$ $\mathrm{cm}$, the radiological assessment is adequate. Every 3 months, the patient will receive additional MELD points equivalent to a $10 \%$ increase in pretransplant mortality as assigned. The listing center must enter an updated MELD Score Exception Application every 3 months in order to receive additional HCC points.

The routine of implementation has included status changes during the first 30 days, after the first 30 days, and after 1 year (Table 1).

Table 1 - How frequently do MELD data get recertified?

\begin{tabular}{lll}
\hline Score & Recertification & Lab Values \\
\hline$\geq 25$ & every 7 days & $\leq 48$ hrs old \\
$24-19$ & every 30 days & $\leq 7$ days old \\
$18-11$ & every 90 days & $\leq 14$ days old \\
$\leq 10$ & every year & $\leq 30$ days old \\
\hline
\end{tabular}

Lab values must be updated according to the recertification schedule above; otherwise, patients will automatically revert to the previous lower MELD score. If there was no previous score available, patients will be assigned a score of 6 . UNet ${ }^{\mathrm{SM}}$ will not accept lab dates outside the ranges shown. For patients with MELD scores $\geq 18$, UNOS Compliance Examiners will call transplant coordinators to alert them before patient scores are automatically adjusted. Calls have been recorded for quality assurance.

\section{HOW IS WAITING TIME USED?}

Waiting time is only used to break ties among patients with same MELD scores and blood type compatibility.

Waiting time is carried backwards but not forwards. When patient moves to a higher MELD score, a new waiting time clock starts. If patient moves to lower MELD score, time accumulated at the higher score or status 1 is included.

\section{HOW HAS MELD AFFECTED ALLOCATION POLICY?}

Status 2A was eliminated from the allocation algorithm 30 days after MELD implementation. Any time spent in $2 \mathrm{~A}$ during said period (up to a total of 30 days) was associated with the patient's first calculated MELD score at the end of the transition period or upon downgrade from a $2 \mathrm{~A}$ to MELD during the transition period. The adult status 1 definition was not changed. The allocation sequence remains local, followed by regional, and then national.

"MELD has been monitored closely since implementation, so that necessary changes can be identified and adopted as more data are collected" ${ }^{34}$.

One drawback attributed to the MELD model is that it only predicts the survival rate of persons on the waiting list prior to liver transplantation, but not the chance of survival after transplantation. However, when we analyzed the model developed by Malinchoc et al. ${ }^{32}$ to access patients' prognosis following transjugular intrahepatic portosystemic shunt (TIPS) procedures, we found that the same variables were used as with the MELD model (levels of bilirubin, creatinine, and INR). The TIPS procedure functions, in effect, like a side-to-side portocaval shunt, promptly reducing portal pressure. The decrease in hepatic sinusoidal pressure decreases the risk of variceal bleeding as well as the formation of ascitis. However, by diverting portal blood flow, TIPS may worsen liver function as well as increase the risk of hepatic encephalopathy in these patients. Some patients do well after TIPS, whereas others fair poorly, and their chances of survival might, in fact, be reduced. However, in their elegant study, Malinchoc et al. showed that patients with low risk ( $\mathrm{R}$ $<1.8, \mathrm{n}=65 ; P=0.88$ ) had better survival rates when compared to patients with a higher risk $(\mathrm{R}>1.8, \mathrm{n}=6 ; P=$ $0.41)$. Thus, although we do not have any information regarding whether the MELD model could be used to predict survival after liver transplantation, the possibility seems reasonable.

In contrast with all the above, in São Paulo, Brazil, since July 7, 1997, allocation priority for livers has been based exclusively on waiting time except in cases of fulminant hepatic failure (FHF) or re-transplantation. In the period between July 1997 to January 2001, 2,450 patients were included on the orthotopic liver transplant waiting list in the city of São Paulo; waiting time was the criterion for selection for transplantation. Of those patients, $1,395(56.9 \%)$ were removed from the list $($ death $=595$; transplanted $=589$; other $=221)$, and $1,052(42.9 \%)$ remained on the list. Of the 595 patients who died on the waiting list, 489 $(82.2 \%)$ died within 1 year of waiting; $224(37.6 \%)$ died between 0 and 3 months; 115 (19.3\%) between 4 and 6 months, and 150 (25.2\%) between 7 and 12 months after inclusion on the list ${ }^{35}$. Theses results corroborate the findings of IOM and Freeman et al. that liver transplant waiting time does not correlate with waiting list mortality but rather with the severity of the liver 
disease. On the other hand, when we looked at the 589 patients who underwent transplantation surgery, we found that the 1-year survival rates were extremely varied among different groups $(50.0 \% \text { to } 82.2 \%)^{36}$. (Fig. 1)

The high mortality rate on the waiting list in São Paulo (25.4\% to $77.8 \%$ ) is striking, horrifying patients, relatives, and physicians. These results should be re-evaluated and taken into consideration by the Brazilian Health Service $^{35}$. The allocation of livers to patients with end-stage liver disease based on the criterion of waiting time is neither fair nor ethical, impares the distributive justice and the human rights, and does not occur in any other part of the world ${ }^{10,37}$.
Finally, we hope that everyone who is involved with liver transplantation, including patients, doctors, authorities, and members of society at large as well, will discover by consensus the way to reduce waiting list mortality, saving the lives of all those patients with end-stage liver disease.

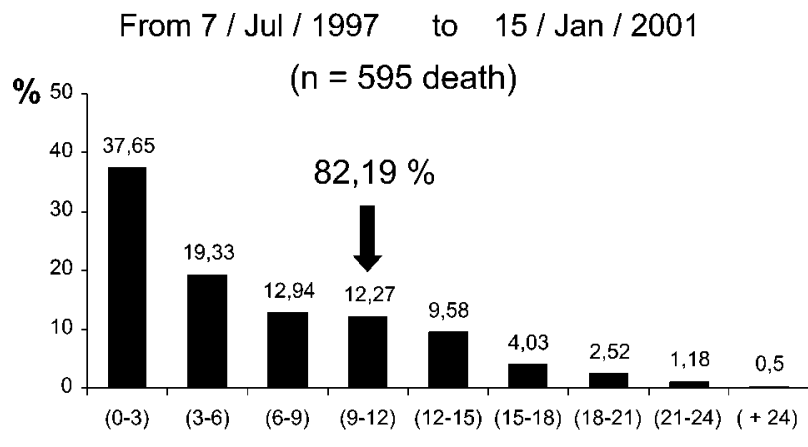

SS-SP

Waiting Time - mos

Figure 1 - Liver transplantation waiting list mortalaty - "Secretaria de Estado da Saúde de São Paulo".

\section{RESUMO}

SETTE Jr. H e col. - Análise crítica da política de alocação de órgãos para transplante de fígado no Brasil.

Rev. Hosp. Clín. Fac. Med. S. Paulo 58(3): 179-184, 2003.

Transplante hepático é tratamento de escolha para pacientes portadores de doença hepática em fase terminal. Pela escassez de órgãos e número crescente de receptores, seleção dos candidatos e otimização do momento do procedimento são necessários. Estratégias foram apontadas: aumento do número de doadores; política justa impossibilitando que idade, sexo, raça, condição financeira façam diferença; conhecimento da história natural de cada doença hepática para a qual o trans- plante hepático é indicado. Para obedecer aos princípios da ética médica e de justiça distributiva (garantia a todo cidadão a mesma oportunidade de obter um enxerto), é necessário estabelecer critérios de gravidade. Estudos (Institute of Medicine e Freeman e col.) demonstraram que tempo de lista não tem relação direta com o número de óbitos e sim com a gravidade dos pacientes no momento da inscrição. Assim, nos EUA, o tempo de lista foi retirado no cálculo para alocação, servindo apenas para diferenciar pacientes igualmente graves. Mortalidade em lista de espera bem como sobrevida de um ano no Estado de São Paulo, onde a alocação obedece critério cronológi- co rígido desde 1997, foram analisados. Dados da Secretaria de Estado da Saúde de São Paulo, no período de julho de 1997 a janeiro de 2001, dentre os óbitos em lista, $82.2 \%$ ocorreram dentro do $1^{\circ}$ ano de lista, sendo $37,6 \%$ nos primeiros 3 meses após a inclusão.

Alocar fígados para transplante obedecendo critério exclusivamente cronológico não é justo ou ético, fere os princípios de justiça distributiva e os direitos humanos, não encontrando similaridade em qualquer outra parte do mundo.

DESCRITORES: Transplante hepático. Critérios de alocação. Modelos prognósticos de sobrevida.

\section{REFERENCES}

1. REUBEN A - Liver transplantation comes of age: indications, timing, and outcomes (Introduction: The Scope of the Problem). AASLD/ILTS - Transpl Course 1997; 1:1-6.

2. GHENT CN - Overall evaluation: sceening and assessment of nonhepatic risk factor. AASLD/ILTS. Transpl Course 1995; 1:1-12.
3. LUCEY MR, BROWN KA, EVERSON GT et al. - Minimal criteria for placement of adults on the liver transplant waiting list: a report of a national conference organized by the American Society of Transplant Physicians and the American Association for the Study of Liver Diseases [see comments]. Liver Transpl Surg 1997; 3:628-37. 
Critical analysis of the allocation policy for liver transplantation Sette Jr. H et al.

4. EMRE S, SCHWARTZ ME, ALTACA G et al. - Safe use of hepatic allografts from donors older than 70 years. Transplantation 1996; 62:62-5.

5. SPITAL A - Mandated choice for organ donation. Transplantation 1997; 63:915.

6. NORMAN D - Allocation of liver transplantation: ethics and politics. Clin Liver Dis 1997; 1:281-286.

7. DICKSON ER, GRAMBSCH PM, FLEMING TR et al. - Prognosis in primary biliary cirrhosis: model for decision making [see comments]. Hepatology 1989; 10:1-7.

8. FARRANT JM, HAYLLAR KM, WILKINSON ML et al. - Natural history and prognostic variables in primary sclerosin cholangitis. Gastroenterology 1991; 100:1710-1717.

9. WIESNER RH, GRAMBSCH PM, DICKSON ER et al. - Primary sclerosing cholangitis: natural history, prognostic factors and survival analysis. Hepatology 1989; 10:430-6.

10. KADRY Z, RENNER EL, CLAVIEN PA - Transplant legislation: ethical and practical issues in liver allocation-The case of Switzerland. Liver Transpl 2001; 7:658-60.

11. REUBEN A - Long-term management of the liver transplant patient: diabetes, hyperlipidemia, and obesity. Liver Transpl 2001; 7:S13-21.

12. WIESNER RH, MENON KV - Late hepatic allograft dysfunction. Liver Transpl 2001; 7:S60-73.

13. BELLAMY CO, DIMARTINI AM, RUPPERT K et al. - Liver transplantation for alcoholic cirrhosis: long term follow-up and impact of disease recurrence. Transplantation 2001; 72:619-26.

14. TESTA G, CRIPPIN JS, NETTO GJ et al. - Liver transplantation for hepatitis $\mathrm{C}$ : recurrence and disease progression in 300 patients. Liver Transpl 2000; 6:553-61.

15. WIESNER RH - Liver transplantation for primary sclerosing cholangitis: timing, outcome, impact of inflammatory bowel disease and recurrence of disease. Best Pract Res Clin Gastroenterol 2001; 15:667-80.

16. HASHIMOTO E, SHIMADA M, NOGUCHI S et al. - Disease recurrence after living liver transplantation for primary biliary cirrhosis: a clinical and histological follow-up study. Liver Transpl 2001; 7:588-95.

17. RATZIU V, SAMUEL D, SEBAGH M et al. - Long-term followup after liver transplantation for autoimmune hepatitis: evidence of recurrence of primary disease. J Hepatol 1999; 30:131-41.

18. MORA N, KLINTMALM G, POPLAWSKI $S$ et al. Recurrence of hepatitis B after liver transplantation. Does hepatitis-Bimmunoglobulin modify the recurrent disease? Transpl Proc 1990; 22:1549-50.

19. SORRELL MF, KEEFFE EB, HENDERSON JM - Long-term management of the liver transplant patient. Liver Transpl 2001; 7:S1.

20. REGISTER F - (codified at 42 CFR \# 121); 1998:16.296.
REV. HOSP. CLÍN. FAC. MED. S. PAULO 58(3):179-184, 2003

21. UBEL PA, CAPLAN AL - Geographic favoritism in liver transplantation-unfortunate or unfair? N Engl J Med 1998; 339:1322-5.

22. SETTE JR. H, BARROS MFA, PESSOA MG et al. - Transplante Hepático: Política de Captação, Alocação e Distribuição de Órgãos no Brasil. GED 2000; 19:28-36.

23. KEEFFE EB - Summary of guidelines on organ allocation and patient listing for liver transplantation. Liver Transpl Surg 1998; 4:S108-14.

24. SHAW JR BW - A collective wisdom. Liver Transpl Surg 1997; 3:680-2.

25. ANONYMOUS - Organ Procurement and Transplantation Network - HRSA. Final rule with comment period. 63: 1629616-338. Washington DC: Federal Register, 1998.

26. MEDICINE IO - Analysis of waiting times. Commmittee on Organ Procurement and Transplantation, ed. Organ Procurement and Transplantation: Assessing Current Policies and Potencial Impact of DHHS Final Rule. Washington, DC: National Academy Press 1999:57-78.

27. FREEMAN JR. RB, EDWARDS EB - Liver transplant waiting time does not correlate with waiting list mortality: implications for liver allocation policy. Liver Transpl 2000; 6:543-52.

28. FORMAN LM, LUCEY MR - Orthotopic liver transplantation for hepatitis C: Analysis of allograft survival using the UNOS database. Am J Transplant 2001; 1:S156A.

29. WIESNER RH, MCDIARMID SV, KAMATH PS et al. - MELD and PELD: application of survival models to liver allocation. Liver Transpl 2001; 7:567-80.

30. FREEMAN RB, ROHRER RJ, KATZ E et al. Preliminary results of a liver allocation plan using a continuous medical severity score that de-emphasizes waiting time. Liver Transpl 2001; 7:173-8.

31. PAYNE WD - Proposing change in organ allocation. Liver Transplant 2001; 7:179-180.

32. MALINCHOC M, KAMATH PS, GORDON FD et al. - A model to predict poor survival in patients undergoing transjugular intrahepatic portosystemic shunts. Hepatology 2000; 31:864-71.

33. KAMATH PS, WIESNER RH, MALINCHOC M et al. - A model to predict survival in patients with end-stage liver disease. Hepatology 2001; 33:464-70.

34. UNOS - IMPORTANT MEMORANDUM: Information Regarding MELD/PELD Implementation.(http://www.unos.org), February 27, 2002

35. SS-SP - SECRETARIA DE ESTADO DA SAÚDE DE SÃO PAULO - Sistema Estadual de Transplantes (http://www.saude.sp.gov.br). Vol. 1997-2001.

36. SS-SP - SECRETARIA DE ESTADO DA SAÚDE DE SÃO PAULO - Dados Oficiais Sobre Sistema Estadual De Transplante. São Paulo: Secretaria de Estado da Saúde de São Paulo, 2001:1112.

37. SETTE JR. H - Transplante Hepático, Critérios de alocação, Conselho Federal de Medicina - Brasília, DF, 18/11/01, 2001. 